\title{
An introduction to the United Kingdom National Accounts
}

The Blue Book presents the full set of economic accounts, or National Accounts, for the United Kingdom. These accounts are compiled by the Office for National Statistics (ONS). They record and describe economic activity in the United Kingdom and as such are used to support the formulation and monitoring of economic and social policies.

This edition of the Blue Book presents estimates of the UK domestic and national product, income and expenditure. Data for 2010 are not yet available for the production account, the generation of income account, Input-Output Supply and Use Tables and for the full detailed industrial analysis of gross value added and its income components.

The accounts are based on the European System of Accounts 1995 (ESA95), ${ }^{1}$ itself based on the System of National Accounts 1993 (SNA93), ${ }^{2}$ which is being adopted by national statistical offices throughout the world. The UK National Accounts have been based on the ESA95 since September 1998. The 1998 edition of the Blue Book explains the main changes; a more detailed explanation of changes can be found in Introducing the ESA95 in the UK. ${ }^{3}$ A detailed description of the structure for the accounts is provided in a separate National Statistics publication National Accounts Concepts, Sources and Methods. ${ }^{4}$

This introduction gives a brief overview of the accounts, explains their framework and sets out the main changes included in this edition of the Blue Book. Definitions of terms used throughout the accounts are included in the glossary. Explanations of more specific concepts are provided within the relevant parts.

The Blue Book comprises five parts:

- Part 1 provides a summary of the UK National Accounts along with explanations and tables that cover the main national and domestic aggregates, for example gross domestic product (GDP) at current market prices and chained volume measures and the GDP deflator; gross value added (GVA) at basic prices; gross national income (GNI); gross national disposable income (GNDI); and where appropriate their equivalents net of capital consumption; population estimates; employment estimates and GDP per head; and the UK summary accounts (the goods and services account, production accounts, distribution and use of income accounts and accumulation accounts). It also includes details of revisions to the data.

- Part 2 includes Input-Output Supply and Use Tables and analyses of gross value added at current market prices and chained volume measures, capital formation and employment, by industry.

- Part 3 provides a description of the institutional sectors as well as explaining different types of transactions, the sequence of the accounts and the balance sheets. Explanation is also given of the statistical adjustment items needed to reconcile the accounts. This part comprises the fullest available set of accounts showing transactions by sectors and appropriate sub-sectors of the economy (including the rest of the world).

- Part 4 covers other additional analyses. It includes tables showing the percentage growth rates of the main aggregates and supplementary tables for capital consumption, gross fixed capital formation, capital stock, non-financial balance sheets, public sector data, and GNI and GNP consistent with the ESA79 compiled for EU budgetary purposes.

- Part 5 covers environmental accounts.

\section{Overview of the accounts}

In the UK, priority is given to the production of a single estimate of GDP using the income, production and expenditure data. The income analysis is available at current prices, expenditure is available at both current prices and chained volume measures, and value added on a quarterly basis is compiled in chained volume measures only. Income, capital and financial accounts are also produced for each of the institutional sectors: non-financial corporations, financial corporations, general government and the households and non-profit institutions serving households. The accounts are fully integrated, but with a statistical discrepancy, known as the statistical adjustment, shown for each sector account (reflecting the difference between the sector net borrowing or lending from the capital account, and the identified borrowing or lending in the financial accounts which should theoretically be equal). Financial transactions and balance sheets are also produced for the rest of the world sector in respect of its dealings with the UK.

\section{Summary of Changes}

While the structure in this edition of the Blue Book remains very close to last years publication, significant changes have been introduced; new industrial and product classifications (SIC 2007 and (PA 2008), improved methods of deflation and some additional improvements, largely in improved methods for the Financial Services and planned revisions to data. The reference 
year has been moved on two years, so that the latest base year for the chained volume measure of GDP is 2008.

\section{The basic framework of the UK National Accounts}

The accounting framework provides for a systematic and detailed description of the UK economy. It includes the sector accounts, which provide, by institutional sector, a description of the different stages of the economic process from production through income generation, distribution and use of income to capital accumulation and financing; and the Input-Output framework, which describes the production process in more detail. It contains all the elements required to compile aggregate measures such as GDP, gross national income (previously known as gross national product), saving and the current external balance (the balance of payments). The economic accounts provide the framework for a system of volume and price indices, so that chained volume measures of aggregates such as GDP can be produced. It should be noted that in this system, value added, from the production approach, is measured at basic prices (including other taxes less subsidies on production but not on products) rather than at factor cost (which excludes all taxes less subsidies on production). The system also encompasses measures of population and employment.

The whole economy is subdivided into institutional sectors. For each sector, current price accounts run in sequence from the production account through to the balance sheet.

The accounts for the whole UK economy and its counterpart, the rest of the world, follow a similar structure to the UK sectors, although several of the rest of the world accounts are collapsed into a single account because they can never be complete when viewed from a UK perspective.

The table numbering system is designed to show the relationships between the UK, its sectors and the rest of the world. A three-part numbering system (for example, 5.2.1) has been adopted for the accounts drawn directly from the ESA95. The first two digits denote the sector; the third digit denotes the ESA account. In this way for example, table 5.2.1 is the central government production account, table 5.3.1 is the local government production account and table 5.3.2 is the local government generation of income account. Not all sectors can have all types of account, so the numbering is not necessarily consecutive within each sector's chapter. For the rest of the world, the identified components of accounts 2-6 inclusive are given in a single account numbered 2 . The UK whole economy accounts consistent with the ESA95 are given in section 1.6 as a time series, and in section 1.7 in detailed matrix format with all sectors, the rest of the world, and the UK total identified.

The ESA95 code for each series is shown in the left-hand column. The ESA95 codes use the prefix ' $S$ ' for the classification of institutional sectors. The ESA95 classification of transactions and other flows comprises transactions in products (prefix P), distributive transactions (prefix D), transactions in financial instruments (prefix $F$ ), and other accumulation entries (prefix K). Balancing items are classified using the prefix $B$. Within the financial balance sheets, financial assets/liabilities are classified using the prefix AF and nonfinancial assets/liabilities using the prefix AN.

\section{What is an account? What is its purpose?}

An account records and displays all of the flows and stocks for a given aspect of economic life. The sum of resources is equal to the sum of uses with a balancing item to ensure this equality. Normally the balancing item will be an economic measure which is itself of interest.

By employing a system of economic accounts we can build up accounts for different areas of the economy which highlight, for example, production, income and financial transactions. In many cases these accounts can be elaborated and set out for different institutional units and groups of units (or sectors). Usually a balancing item has to be introduced between the total resources and total uses of these units or sectors and, when summed across the whole economy, these balancing items constitute significant aggregates. Table A provides the structure of the accounts and shows how GDP estimates are derived as the balancing items.

\section{The integrated economic accounts}

The integrated economic accounts of the UK provide an overall view of the economy. Figure 1 presents a summary view of the accounts, balancing items and main aggregates and shows how they are expressed.

The accounting structure is uniform throughout the system and applies to all units in the economy, whether they are institutional units, sub-sectors, sectors or the whole economy, though some accounts (or transactions) may not be relevant for some sectors.

The accounts are grouped into four main categories: goods and services account, current accounts, accumulation accounts and balance sheets.

\section{The goods and services account (Account 0)}

The goods and services account is a transactions account which balances total resources, from output and imports, against the uses of these resources in consumption, investment, inventories and exports. As the resources are simply balanced with the uses, there is no balancing item. The goods and services account is discussed in detail in chapters 3 and 12 of National Accounts Concepts, Sources and Methods. ${ }^{4}$

\section{Current accounts: the production accounts and the distribution of income accounts}

Current accounts deal with production, distribution of income and use of income. 


\section{The production account (Account I)}

The production account displays the transactions involved in the generation of income by the activity of producing goods and services. In this case the balancing item is value added (B.1). For the nation's accounts, the balancing item (the sum of value added for all industries) is, after the addition of taxes less subsidies on products, gross domestic product (GDP) at market prices or net domestic product when measured net of capital consumption. The production accounts are also shown for each institutional sector.

The production accounts are discussed in detail in Chapters 4 and 13 of National Accounts Concepts, Sources and Methods. ${ }^{4}$

\section{Distribution and use of income account (Account II)}

The distribution and use of income account shows the distribution of current income (in this case value added) carried forward from the production account, and has as its balancing item saving (B.8), which is the difference between income (disposable income) and expenditure (or final consumption). There are three sub-accounts which break down the distribution of income into the primary distribution of income, the secondary distribution of income and the redistribution of income in kind.

Primary incomes are those that accrue to institutional units as a consequence of their involvement in production, or their ownership of productive assets. They include property income (from lending or renting assets) and taxes on production and imports, but exclude taxes on income or wealth, social contributions or benefits and other current transfers. The primary distribution of income shows the way these are distributed among institutional units and sectors. The primary distribution account is itself divided into two sub-accounts the generation and the allocation of primary incomes - but the further breakdown in the ESA95 of the allocation of primary income account into an entrepreneurial income account and an allocation of other primary income account has not been adopted in the UK.

The secondary distribution of income account shows how the balance of primary incomes for an institutional unit or sector is transformed into its disposable income by the receipt and payment of current transfers (excluding social transfers in kind). A further two sub-accounts - the use of disposable income and the use of adjusted disposable income - look at the use of income for either consumption or saving. These accounts are examined in detail in Chapters 5 and 14 of National Accounts Concepts, Sources and Methods. ${ }^{4}$

Aggregated across the whole economy the balance of the primary distribution of income provides national income (B.5) (which can be measured net or gross), the balance of the secondary distribution of income in kind provides national disposable income (B.6), and the balance of the use of income accounts provides national saving (B.8). These are shown in Figure 1.

\section{The accumulation accounts (Accounts III and IV)}

The accumulation accounts cover all changes in assets, liabilities and net worth (the difference for any sector between its assets and liabilities). The accounts are structured to allow various types of change in these elements to be distinguished.

The first group of accounts covers transactions which would correspond to all changes in assets/liabilities and net worth which result from transactions for example, savings and voluntary transfers of wealth (capital transfers). These accounts are the capital account and financial account which are distinguished in order to show the balancing item net lending/ borrowing (B.9).

The second group of accounts relates to changes in assets, liabilities and net worth due to other factors (for example the discovery or re-evaluation of mineral reserves, or the reclassification of a body from one sector to another).

\section{Capital account (Account III.1)}

The capital account concerns the acquisition of non-financial assets (some of which will be income creating and others which are wealth only) such as fixed assets or inventories, financed out of saving, and capital transfers involving the redistribution of wealth. Capital transfers include for example, capital grants from private corporations to public corporations. This account shows how saving finances investment in the economy. In addition to gross fixed capital formation and changes in inventories, it shows the redistribution of capital assets between sectors of the economy and the rest of the world. The balance on the capital account, if negative, is designated net borrowing, and measures the net amount a unit or sector is obliged to borrow from others; if positive the balance is described as net lending, the amount the UK or a sector has available to lend to others. This balance is also referred to as the financial surplus or deficit and the net aggregate for the five sectors of the economy equals net lending/borrowing from the rest of the world.

\section{Financial account (Account III.2)}

The financial account shows how net lending and borrowing are achieved by transactions in financial instruments. The net acquisitions of financial assets are shown separately from the net incurrence of liabilities. The balancing item is again net lending or borrowing.

In principle net lending or borrowing in the capital account should be identical to net lending or borrowing on the financial account. However in practice, because of errors and omissions, this identity is very difficult to achieve for the sectors and the 


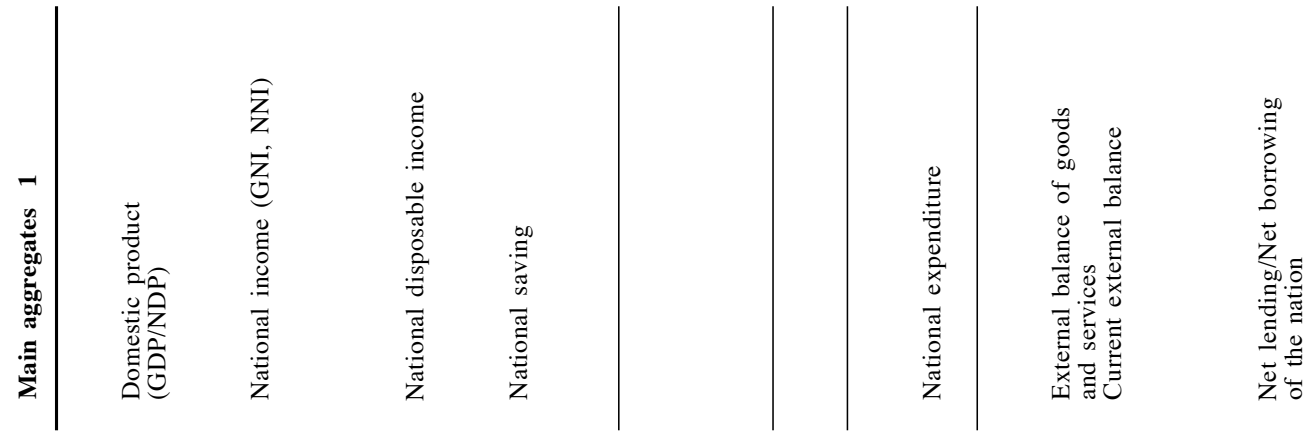

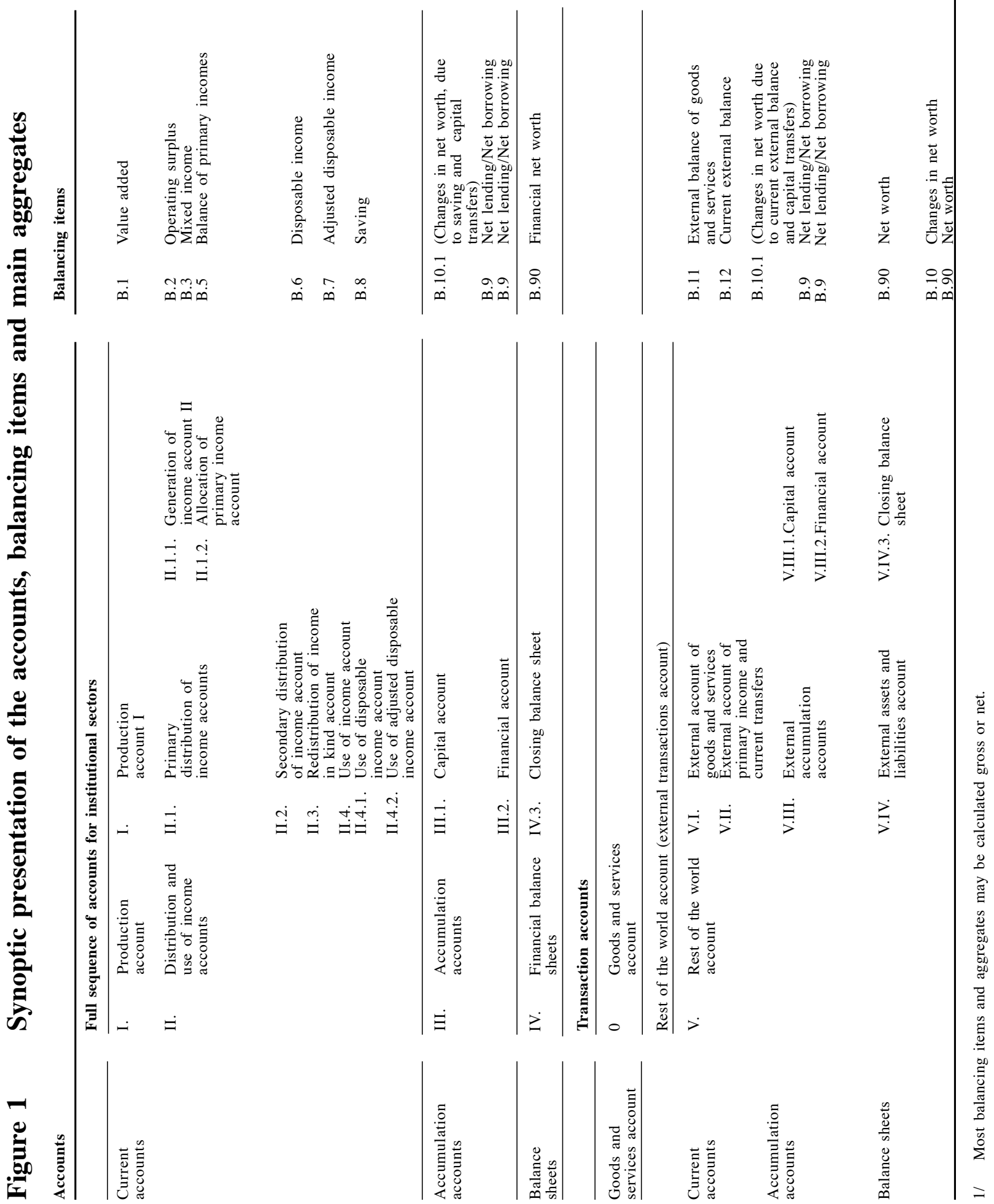


economy as a whole. The difference is known as the statistical discrepancy (previously known as the balancing item).

\section{The balance sheet (Account IV)}

The sequence of accounts is completed by the second group of accumulation accounts. These include the balance sheets and a reconciliation of the changes that have brought about the change in net worth between the beginning and the end of the accounting period.

The opening and closing balance sheets show how total holdings of assets by the UK or its sectors match total liabilities and net worth (the balancing item). In detailed presentations of the balance sheets the various types of asset and liability can be shown. Changes between the opening and closing balance sheets for each group of assets and liabilities result from transactions and other flows recorded in the accumulation accounts, or reclassifications and revaluations. Net worth equals changes in assets less changes in liabilities.

\section{Rest of the world account (Account V)}

This account covers the transactions between resident and non-resident institutional units and the related stocks of assets and liabilities. The rest of the world plays a similar role to an institutional sector and the account is written from the point of view of the rest of the world. This account is discussed in detail in chapter 24 of National Accounts Concepts, Sources and Methods. ${ }^{4}$

\section{Satellite accounts}

Satellite accounts are accounts which involve areas or activities not dealt with in the central framework above, either because they add additional detail to an already complex system or because they actually conflict with the conceptual framework. The UK has begun work on a number of satellite accounts and one such - the UK environmental accounts - links environmental and economic data in order to show the interactions between the economy and the environment. Summary information from the environmental accounts is presented in part 5. More detailed information on the environmental accounts is available from the ONS website at: http://www.ons.gov.uk/ons/rel/environmental/environmentalaccounts/2011/index.html

\section{Some definitions}

The text within Sections 1-3 explains the sources and methods used in the estimation of the UK economic accounts, but it is sensible to precede them with an explanation of some of the basic concepts and their 'UK specific' definitions, namely:

- the limits of the UK national economy: economic territory, residency and centre of economic interest

- economic activity: what production is included - the production boundary what price is used to value the products of economic activity

- estimation or imputation of values for non-monetary transactions

the rest of the world: national and domestic

A full description of the accounting rules is provided in Chapter 2 of National Accounts Concepts, Sources and Methods. ${ }^{4}$

The limits of the national economy: economic territory, residence and centre of economic interest

The economy of the United Kingdom is made up of institutional units (see chapter 10 of National Accounts Concepts, Sources and Methods ${ }^{4}$ ) which have a centre of economic interest in the UK economic territory. These units are known as resident units and it is their transactions which are recorded in the UK National Accounts. The definitions of these terms are given below:

The UK economic territory is made up of:

- Great Britain and Northern Ireland (the geographic territory administered by the UK government within which persons, goods, services and capital move freely)

- any free zones, including bonded warehouses and factories under UK customs control

- the national airspace, UK territorial waters and the UK sector of the continental shelf

It excludes the offshore islands, the Channel Islands and the Isle of Man, which are not part of the United Kingdom or members of the European Union.

Within the ESA95 the definition of economic territory also includes:

- territorial enclaves in the rest of the world (embassies, military bases, scientific stations, information or immigration offices, aid agencies, used by the British government with the formal political agreement of the governments in which these units are located)

but excludes:

- any extra territorial enclaves (that is, parts of the UK geographic territory like embassies and US military bases used by general government agencies of other countries, by the institutions of the European Union or by international organisations under treaties or by agreement)

\section{Centre of economic interest and residency}

An institutional unit has a centre of economic interest and is a resident of the UK when, from a location (for example, a dwelling, place of production or premises) within the UK economic territory, it engages and intends to continue engaging (indefinitely or for a finite period; one year or more is 
used as a guideline) in economic activities on a significant scale. It follows that if a unit carries out transactions on the economic territory of several countries it has a centre of economic interest in each of them (for example, BP has an interest in many countries where it is involved in the exploration and production of oil and gas). Ownership of land and structures in the UK is enough to qualify the owner to have a centre of interest here.

Within the definition given above resident units are households, legal and social entities such as corporations and quasi corporations (for example, branches of foreign investors), non-profit institutions and government. Also included here however are so called 'notional residents'.

Travellers, cross border and seasonal workers, crews of ships and aircraft, and students studying overseas are all residents of their home countries and remain members of their households. However an individual who leaves the UK for a year or more (except students and patients receiving medical treatment) ceases to be a member of a resident household and becomes a non-resident even on home visits.

\section{Economic activity: what production is included?}

As GDP is defined as the sum of all economic activity taking place in UK territory, having defined the economic territory it is important to be clear about what is defined as economic activity. In its widest sense it could cover all activities resulting in the production of goods or services and so encompass some activities which are very difficult to measure. For example, estimates of smuggling of alcoholic drink and tobacco products, and the output, expenditure and income directly generated by that activity, have been included since the 2001 edition of the Blue Book.

In practice a 'production boundary' is defined, inside which are all the economic activities taken to contribute to economic performance. This economic production may be defined as activity carried out under the control of an institutional unit that uses inputs of labour or capital and goods and services to produce outputs of other goods and services. These activities range from agriculture and manufacturing through service producing activities (for example, financial services and hotels and catering) to the provision of health, education, public administration and defence; they are all activities where an output is owned and produced by an institutional unit, for which payment or other compensation has to be made to enable a change of ownership to take place. This omits purely natural processes.

The decision whether to include a particular activity within the production boundary takes into account the following:

- does the activity produce a useful output?

- is the product or activity marketable and does it have a market value?
- if the product does not have a meaningful market value can a market value be assigned (that is, can a value be imputed)?

- would exclusion (or inclusion) of the product of the activity make comparisons between countries or over time more meaningful?

In practice the ESA95 production boundary can be summarised as follows:

The production of all goods whether supplied to other units or retained by the producer for own final consumption or gross capital formation, and services only in so far as they are exchanged in the market and/or generate income for other economic units.

For households this has the result of including the production of goods on own-account, for example the produce of farms consumed by the farmer's own household (however, in practice produce from gardens or allotments has proved impossible to estimate in the United Kingdom). The boundary excludes the production of services for own final consumption (household domestic and personal services like cleaning, cooking, ironing and the care of children and the sick or infirm). Although the production of these services does take considerable time and effort, the activities are self-contained with limited repercussions for the rest of the economy and, as the vast majority of household domestic and personal services are not produced for the market, it is very difficult to value the services in a meaningful way.

\section{What price is used to value the products of economic activity?}

In the UK a number of different prices may be used to value inputs, outputs and purchases. The prices are different depending on the perception of the bodies engaged in the transaction, that is, the producer and user of a product will usually perceive the value of the product differently, with the result that the output prices received by producers can be distinguished from the prices paid by purchasers.

These different prices - purchasers' (or market) prices, basic prices and producers' prices - are looked at in turn below. They differ as a result of the treatment of taxes less subsidies on products, and trade and transport margins. Although the factor cost valuation (see explanation in Part 1) is not required under the SNA93 or the ESA95, ONS will continue to provide figures for gross value added at factor cost for as long as customers continue to find this analysis useful.

\section{Basic prices}

These prices are the preferred method of valuing output in the accounts. They reflect the amount received by the producer for a unit of goods or services, minus any taxes payable, and plus any subsidy receivable on that unit as a consequence of production or sale (that is, the cost of production including 
subsidies). As a result the only taxes included in the price will be taxes on the output process - for example business rates and vehicle excise duty - which are not specifically levied on the production of a unit of output. Basic prices exclude any transport charges invoiced separately by the producer. When a valuation at basic prices is not feasible then producers' prices may be used.

\section{Producers' prices}

Producers' prices equal basic prices plus those taxes paid per unit of output (other than taxes deductible by the purchaser, such as VAT, invoiced for output sold) less any subsidies received per unit of output.

\section{Purchasers' or Market prices}

These are the prices paid by the purchaser and include transport costs, trade margins and taxes (unless the taxes are deductible by the purchaser).

Purchasers' prices equal producers' prices plus any non-deductible VAT or similar tax payable by the purchaser, plus transport costs paid separately by the purchaser and not included in the producers' price.

'Purchaser's prices' are also referred to as 'market prices', for example 'GDP at market prices'.

\section{The rest of the world: national and domestic}

Domestic product (or income) includes production (or primary incomes generated and distributed) resulting from all activities taking place 'at home' or in the UK domestic territory. This will include production by any foreign owned company in the United Kingdom but exclude any income earned by UK residents from production taking place outside the domestic territory. Thus gross domestic product is also equal to the sum of primary incomes distributed by resident producer units.

The definition of gross national income can be introduced by considering the primary incomes distributed by the resident producer units above. These primary incomes, generated in the production activity of resident producer units, are distributed mostly to other residents' institutional units. For example, when a resident producer unit is owned by a foreign company, some of the primary incomes generated by the producer unit are likely to be paid abroad. Similarly, some primary incomes generated in the rest of the world may go to resident units. Thus, when looking at the income of the nation, it is necessary to exclude that part of resident producers' primary income paid abroad, but include the primary incomes generated abroad but paid to resident units; that is:

Gross domestic product (or income)

$$
\text { less }
$$

primary incomes payable to non-resident units

\author{
plus \\ primary incomes receivable from the rest of the world \\ equals \\ Gross national income
}

Thus gross national income (GNI) at market prices is the sum of gross primary incomes receivable by resident institutional units/ sectors.

National income includes income earned by residents of the national territory, remitted (or deemed to be remitted in the case of direct investment) to the national territory, no matter where the income is earned; that is:

Real GDP (chained volume measures)

\section{plus}

trading gain

equals

Real gross domestic income (RGDI)

Real gross domestic income (RGDI)

plus

real primary incomes receivable from abroad

less

real primary incomes payable abroad

equals

Real gross national income (real GNI)

Real GNI (chained volume measures)

plus

real current transfers from abroad

less

real current transfers abroad

equals

Real gross national disposable income (real GNDI)

Receivables and transfers of primary incomes, and transfers to and from abroad are deflated using the index of gross domestic final expenditure.

\section{Gross domestic product: the concept of net and gross}

The term gross refers to the fact that when measuring domestic production we have not allowed for an important phenomenon: capital consumption or depreciation. Capital goods are different from the materials and fuels used up in the 
production process because they are not used up in the period of account but are instrumental in allowing that process to take place. However over time, capital goods wear out or become obsolete and in this sense gross domestic product does not give a true picture of value added in the economy. In other words, in calculating value added as the difference between output and costs we should include as a current cost that part of the capital goods used up in the production process; that is, the depreciation of the capital assets.

Net concepts are net of this capital depreciation, for example:

Gross domestic product

$$
\begin{aligned}
& \text { minus } \\
& \text { consumption of fixed capital } \\
& \text { equals } \\
& \text { Net domestic product }
\end{aligned}
$$

However, because of the difficulties in obtaining reliable estimates of the consumption of fixed capital (depreciation), gross domestic product remains the most widely used measure of economic activity.

\section{Symbols and conventions used}

\section{Symbols}

In general, the following symbols are used:

.. not available

- $\quad$ nil or less than $£ 500,000$

$\mathrm{f}$ billion denotes $\mathrm{f} 1,000$ million.

\section{Sign conventions}

\section{Resources and Uses}

Increase shown positive

Decrease shown negative

\section{Capital account}

Liabilities, net worth and Assets:

Increase shown positive

Decrease shown negative

\section{Financial account}

$$
\begin{array}{ll}
\text { Assets: } & \text { net acquisition shown positive } \\
& \text { net disposal shown negative } \\
\text { Liabilities: } & \text { net acquisition shown positive } \\
& \text { net disposal shown negative }
\end{array}
$$

\section{Balance sheet}

Assets and liabilities each shown positive

Balance shown positive if net asset, negative if net liability

\section{References}

1. Eurostat (1995) European System of Accounts 1995 (ESA95) http://circa.europa.eu/irc/dsis/nfaccount/info/data/esa95/ esa95-new.htm

2. UN, OECD, IMF, EU (1993) System of National Accounts 1993 (SNA93)

http://unstats.un.org/unsd/nationalaccount/sna1993.asp

3. Office for National Statistics (1998) Introducing the ESA95 in the UK. ISBN 011621061 3. The Stationery Office: London.

4. Office for National Statistics (1998) National Accounts Concepts, Sources and Methods. http://www.ons.gov.uk/ons/rel/naa1-rd/national-accountsconcepts--sources-and-methods/1998-release/index.html

\section{Articles}

Akritidis L (2002) Accuracy assessment of National Accounts statistics. Economic Trends, No. 589.

http://www.ons.gov.uk/ons/rel/elmr/economic-trends-discontinued-/no--589--november-2002/index.html

Baxter M (2000) Developments in the measurement of general government output. Economic Trends, No. 562. http://www.ons.gov.uk/ons/rel/elmr/economic-trends-discontinued-/no--562--september-2000/index.html

Clancy G and Gittins P (2011) Blue Book 2011: Improvements to Household Expenditure estimates http://www.ons.gov.uk/ons/rel/consumer-trends/blue-book2011--improvements-to-household-expenditure-estimates/ q2-2011/art---blue-book-2011--improvements-to-householdexpenditure-estimates.html

Drew S (2011) Deflation Improvements in the UK National Accounts http://www.ons.gov.uk/ons/rel/naa1-rd/national-accountsconcepts--sources-and-methods/august-2011/deflationimprovements-in-the-uk-national-accounts.pdf

Drew S and Dunn M (2011) Blue Book 2011: Reclassification of the UK Supply and Use tables

http://www.ons.gov.uk/ons/rel/input-output/input-outputsupply-and-use-tables/reclassification-of-the-uk-supply-anduse-tables/index.html

Duff H (2011) Blue Book 2011: Improvements to GDP(O), loS and IoP http://www.ons.gov.uk/ons/dcp171766_229044.pdf 
Duff S (2011) Improving the coverage of derivatives data in the National Accounts and Balance of Payments

http://www.ons.gov.uk/ons/rel/naa1-rd/united-kingdomeconomic-accounts/improving-the-coverage-of-derivativesdata-in-the-national-accounts-and-balance-of-payments/ art-improving-the-coverage-of-derivatives-data-in-na-and-bop. html

Everett G (2011) Historic National Accounts data proposals for Blue Book 2011

http://www.ons.gov.uk/ons/rel/naa1-rd/united-kingdomnational-accounts/historic-national-accounts-data-proposalsfor-blue-book-2011/ard-historic-national-accounts-dataproposals-fopr-blue-book-2011.pdf

Everett G (2011) Methods Changes in the 2011 Blue Book http://www.ons.gov.uk/ons/rel/naa1-rd/united-kingdomnational-accounts/method-changes-in-blue-book-2011/ ard-method-changes-in-blue-book-2011.pdf

Fletcher D and Williams M (2002) Index of Production redevelopment. Economic Trends, No. 587.

http://www.ons.gov.uk/ons/rel/elmr/economic-trends-discontinued-/no--587--september-2002/index.htm

Jenkinson G (1997) Quarterly integrated economic accounts The United Kingdom approach. Economic Trends Digest of Articles.

http://www.ons.gov.uk/ons/rel/elmr/economic-trends-discontinued-/economic-trends-digest-of-articles/index.html

Jones $G$ (2000) The development of the annual business inquiry. Economic Trends, No. 564.

http://www.ons.gov.uk/ons/rel/elmr/economic-trends-discontinued-/no--564--november-2000/index.html

Lee P (2011) UK National Accounts - a short guide. http://www.ons.gov.uk/ons/rel/naa1-rd/united-kingdomnational-accounts/2010-edition/uk-national-accounts---a-shortguide.pdf
Powell M and Swatch N (2002) An investigation into the coherence of deflation methods in the National Accounts. Economic Trends, No. 588.

http://www.ons.gov.uk/ons/rel/elmr/economic-trends-discontinued-/no--588--october-2002/index.html

Pritchard A (2003) Understanding government output and productivity. Economic Trends, No. 596.

http://www.ons.gov.uk/ons/rel/elmr/economic-trends-discontinued-/no--596-june-2003/index.html

Ruffles D, Tily G, Caplan D and Tudor S (2003) VAT missing trader intra-community fraud: The effect on balance of payments statistics and UK National Accounts. Economic Trends, No. 597. http://www.ons.gov.uk/ons/rel/elmr/economic-trends-discontinued-/no--598--august-2003/vat-missing-trader-intracommunity-fraud--the-effect-on-balance-of-paymentsstatistics---uk-national-accounts-.pdf

Sheerin C (2002) UK Material Flow Accounting. Economic Trends, No. 583.

http://www.ons.gov.uk/ons/rel/elmr/economic-trends-discontinued-/no--583--june-2002/index.html

Skipper H (2005) Early estimates of GDP: information content and forecasting methods. Economic Trends, No. 617. http://www.ons.gov.uk/ons/rel/elmr/economic-trends-discontinued-/no--617--april-2005/index.html

Soo A and Charmokly Z (2003) The application of annual chain-linking to the Gross National Income system. Economic Trends, No. 593.

http://www.ons.gov.uk/ons/rel/elmr/economic-trends-discontinued-/no--593--march-2003/index.html

Tuke A and Beadle J (2003) The effect of annual chain-linking on Blue Book 2002 annual growth estimates. Economic Trends, No. 593.

http://www.ons.gov.uk/ons/rel/elmr/economic-trends-discontinued-/no--593--march-2003/index.html 


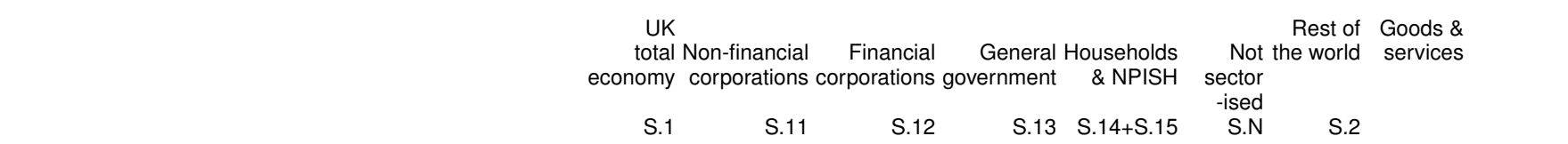

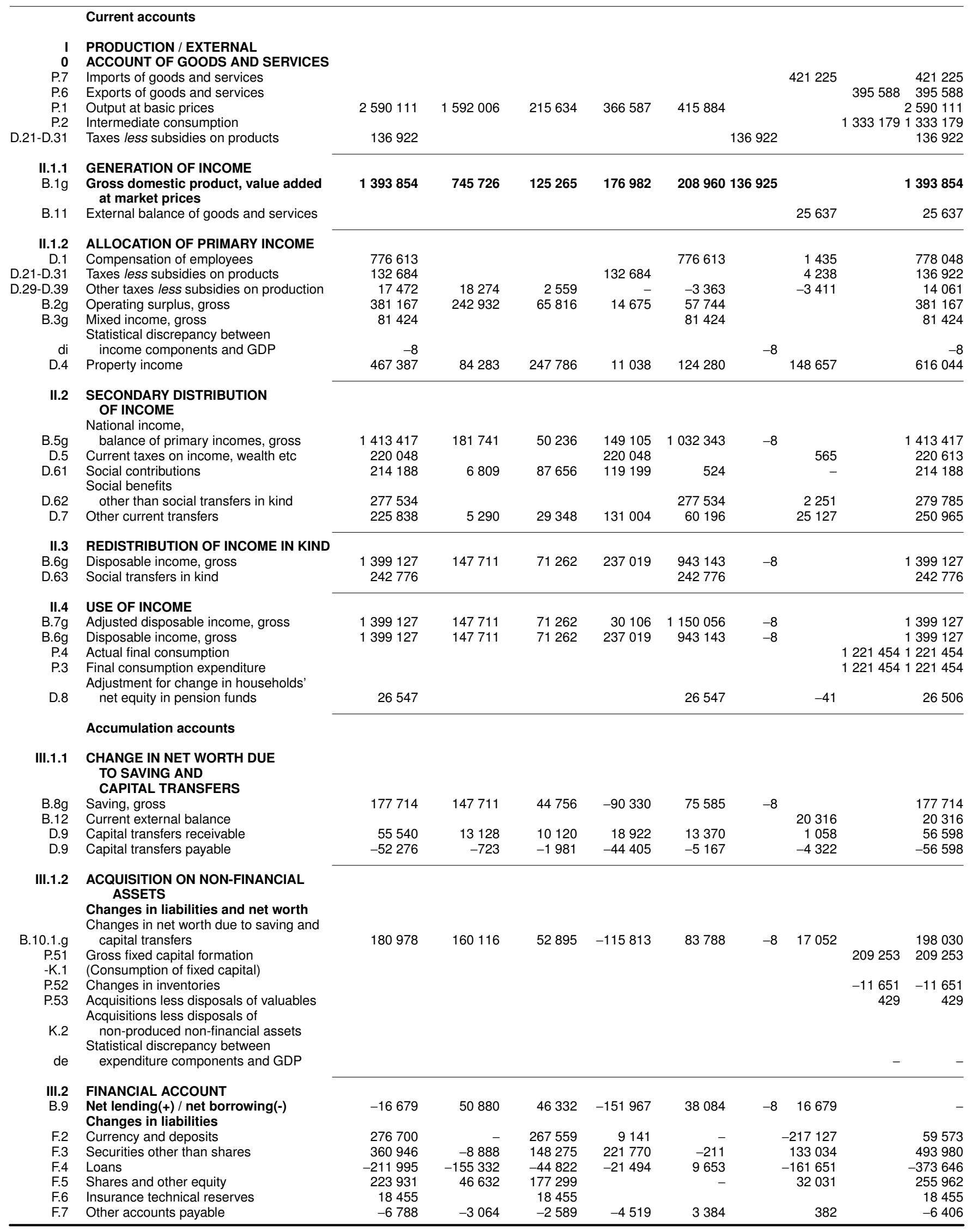




\section{Current accounts}

I PRODUCTION / EXTERNAL

0 ACCOUNT OF GOODS AND SERVICES

P.7 Imports of goods and services

P.6 Exports of goods and services

P.1 Output at basic prices

P2 Intermediate consumption

D.21-D.31 Taxes less subsidies on products

B.1g Gross domestic product, value added at market prices

B.11 External balance of goods and services

II.1.1 GENERATION OF INCOME

D.1 Compensation of employees

D.21-D.31 Taxes less subsidies on products

D.29-D.39 Other taxes less subsidies on production

B.2g Operating surplus, gross

B.3g Mixed income, gross

Statistical discrepancy between

di income components and GDP

II.1.2 ALLOCATION OF PRIMARY INCOME

D.4 Property income

National income

B. $5 \mathrm{~g}$ balance of primary incomes, gross

II.2 SECONDARY DISTRIBUTION OF INCOME

D.5 Current taxes on income, wealth etc

D.61 Social contributions

Social benefits

D.62 other than social transfers in kind

D.7 Other current transfers

B.6g Disposable income, gross

II.3 REDISTRIBUTION OF INCOME IN KIND

B.7g Adjusted disposable income, gross

D.63 Social transfers in kind

II.4 USE OF INCOME

B.6g Disposable income, gross

P.4 Actual final consumption

P.3 Final consumption expenditure

Adjustment for change in households

D.8 net equity in pension funds

B.8g Saving, gross

B.12 Current external balance

Accumulation accounts

III.1.1 CHANGE IN NET WORTH

DUE TO SAVING AND

CAPITAL TRANSFERS

D.9 Capital transfers receivable

D.9 Capital transfers payable

Changes in net worth due to saving

B.10.1.g and capital transfers

III.1.2 ACQUISITION OF NON-FINANCIAL ASSETS

Changes in assets

P.51 Gross fixed capital formation

-K.1 (Consumption of fixed capital)

P.52 Changes in inventories

P.53 Acquisitions less disposals of valuables

Acquisitions less disposals of

K.2 non-produced non-financial assets

Statistical discrepancy between

de expenditure components and GDP

B.9 Net lending(+) / net borrowing(-)

III.2 FINANCIAL ACCOUNT: changes in assets

F.1 Monetary gold and SDRs

F.2 Currency and deposits

F.3 Securities other than shares

F.4 Loans

F.5 Shares and other equity

F.6 Insurance technical reserves

F.7 Other accounts receivable

Statistical discrepancy between non-financial

dB.9f and financial transactions

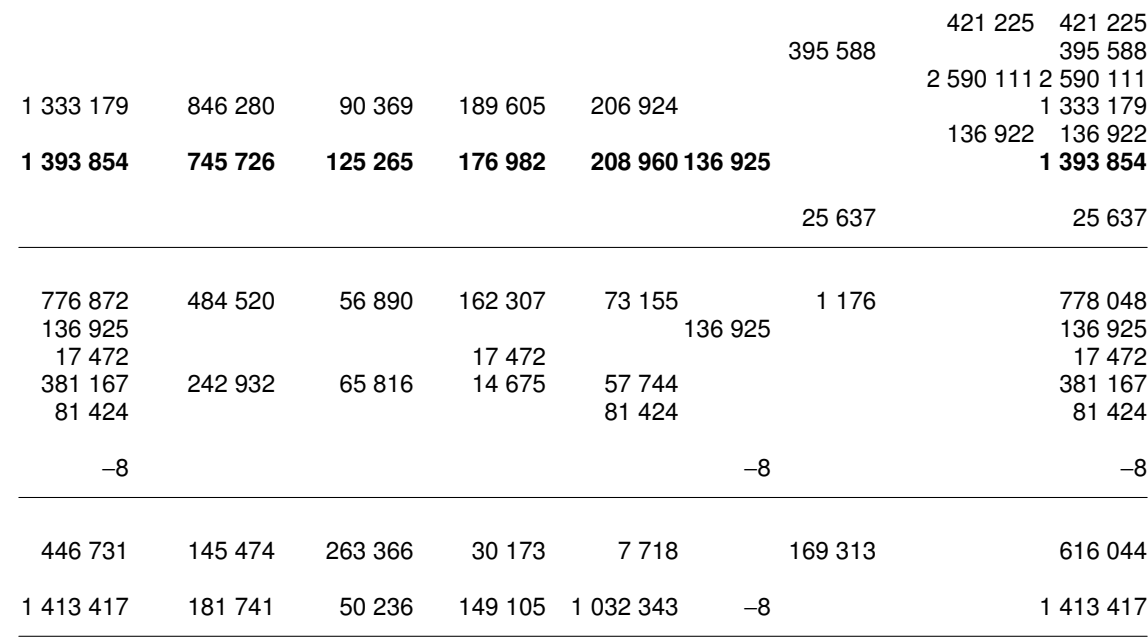

\begin{tabular}{|c|c|c|c|c|c|c|}
\hline $\begin{array}{l}219941 \\
214016\end{array}$ & 33542 & 5400 & 1189 & $\begin{array}{l}179810 \\
214016\end{array}$ & $\begin{array}{l}672 \\
172\end{array}$ & $\begin{array}{l}220613 \\
214188\end{array}$ \\
\hline $\begin{array}{r}279785 \\
238156 \\
1399127\end{array}$ & $\begin{array}{r}6809 \\
5778 \\
147711\end{array}$ & $\begin{array}{ll}61 & 150 \\
29 & 428 \\
71 & 262\end{array}$ & $\begin{array}{l}210806 \\
170342 \\
237019\end{array}$ & $\begin{array}{r}1020 \\
32608 \\
943143\end{array}$ & $\begin{array}{ll} & 12809 \\
-8 & \end{array}$ & $\begin{array}{r}279785 \\
250965 \\
1399127\end{array}$ \\
\hline $\begin{array}{r}1399127 \\
242776\end{array}$ & 147711 & 71262 & $\begin{array}{r}30106 \\
206913\end{array}$ & $\begin{array}{r}1150056 \\
35863\end{array}$ & -8 & $\begin{array}{r}1399127 \\
242776\end{array}$ \\
\hline $\begin{array}{l}1221454 \\
1221454\end{array}$ & & & $\begin{array}{l}120436 \\
327349\end{array}$ & $\begin{array}{r}1101018 \\
894105\end{array}$ & & $\begin{array}{l}1221454 \\
1221454\end{array}$ \\
\hline $\begin{array}{r}26506 \\
177714\end{array}$ & 147711 & $\begin{array}{l}26506 \\
44756\end{array}$ & -90330 & 75585 & 20316 & $\begin{array}{r}26506 \\
177714 \\
20316\end{array}$ \\
\hline
\end{tabular}

$\begin{array}{llllllll}180978 & 160116 & 52895 & -115813 & 83788 & -8 & 17052 & 198030\end{array}$

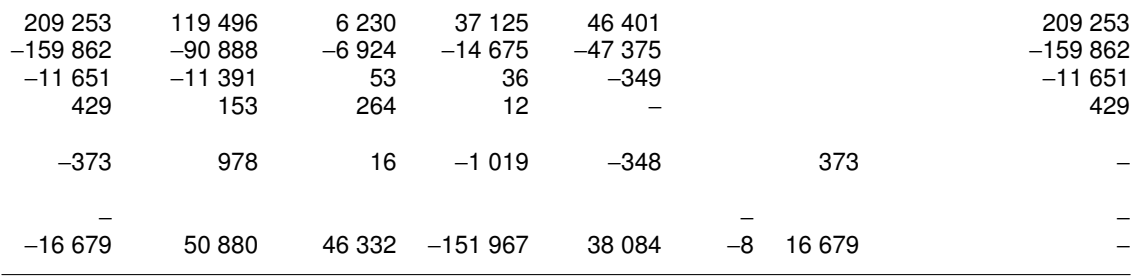

$-132$

383511

354494

$-275945$

162292

18778

$-6514$

8086
$-6138 \quad 355515$

$-46465-232060$

$24132 \quad 87240$

$-354 \quad-37$

-5635
-3176

$-1378$

851

\section{$-132$}

9674

1883

14947

132

$-1892$

-323938
139486

139486
-97701

13568
19193

$\begin{array}{ll}-24 & 19193 \\ 403 & -7458\end{array}$

93670

$-323$

9318

$-8 \quad-8086$
-33 $934 \quad 392824$
59573

493980

$-373646$

255962

255962
18455

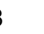




\section{Calendar of economic events: 1990-2010}

1990

Mar Budget introduces tax exempt savings accounts (TESSAs)

Apr New Education Act brings in student loans

Community Charge ('poll tax') introduced

Aug Kuwait invaded by Iraq

Oct Official reunification of Germany

UK enters Exchange Rate Mechanism

Nov John Major replaces Margaret Thatcher as Prime Minister

Privatisation of electricity boards

1991

Jan NHS internal market created

Gulf War begins

Feb Gulf War ends

Mar Air Europe collapses

Budget restricts mortgage interest relief to basic rate:

Corporation Tax reduced and VAT increased

Jul Bank of Credit and Commerce International closed by Bank of England

Nov Maastricht agreement signed with UK opt-outs

\section{2}

Jan Russia agrees to join the IMF

Feb 'Delors Package' raises EC's spending limits to 1.37 per cent of GDP to aid poorer member states

Mar Budget raises lower rate of income tax to 20 per cent

Apr Conservatives win General Election, John Major remains Prime Minister

May Swiss vote in a referendum to join the IMF and International Bank for Reconstruction and Development

Reform of EC Common Agricultural Policy agreed, switching from farm price support to income support

Sep 'Black Wednesday': UK leaves Exchange Rate Mechanism

Oct North American Free Trade Agreement (NAFTA) signed

Nov Bill Clinton defeats George Bush in US presidential election

\section{3}

Jan Council Tax announced as replacement for Community Charge
Mar Budget imposes VAT on domestic fuel

Nov Parliament votes to relax Sunday trading rules

First autumn Budget cuts public expenditure and increases taxes

1994

Jan European Economic Area formed linking EU and European Free Trade Area

Apr Eurotunnel opens

Nov First draw of National Lottery

Dec Coal industry privatised

\section{5}

Jan EU expanded to include Sweden, Finland and Austria World Trade Organisation succeeds General Agreement on Tariffs and Trade

Feb Barings Bank collapses

1996

Jan Gilt 'repo' market established

Mar Rebates worth $f 1$ billion paid to electricity consumers after break up of National Grid

May Railtrack privatised, reducing public sector borrowing requirement (PSBR) by $\mathrm{f} 1.1$ billion

Aug CREST clearing system initiated

Sep Privatisation of National Power and PowerGen reduces PSBR by a further $£ 1.0$ billion

1997

Apr Alliance and Leicester Building Society converts to bank

May Labour Party wins general election, Tony Blair becomes Prime Minister

Chancellor announces operational independence for the Bank of England, decisions on interest rates to be taken by a new Monetary Policy Committee

Jun Halifax Building Society converts to a bank Norwich Union floated on the stock market

Jul Gordon Brown presents his first Budget, setting inflation target of 2.5 per cent based on the Retail Prices Index excluding mortgage interest payments (RPIX) Woolwich Building Society converts to a bank 
Bristol and West Building Society converts to a bank

Aug Stock market falls in Far East, Hang Seng Index ending 20 per cent lower than a year earlier

Economic and financial crisis in Russia

Dec The first instalment of the windfall tax on utilities ( $\mathrm{f} 2.6$ billion) is paid

1998

Apr Sterling Exchange Rate Index hits its highest point since 1989

Mortgage payments rise as Mortgage Interest Relief at Source is cut from 15 per cent to 10 per cent

The New Deal for the unemployed is introduced

Jun The Bank of England's 'repo' rate is raised by 0.25 per cent to a peak of 7.5 per cent

Economic and Fiscal Strategy Report announces new format for public finances, distinguishing between current and capital spending

Aug BP merges with Amoco to create the UK's largest company

Oct The Working Time Directive, setting a 48-hour week, takes effect

Dec The second instalment of the windfall tax on utilities ( $\mathrm{f} 2.6$ billion) is paid

Ten of the eleven countries about to enter the euro harmonise interest rates at 3.0 per cent

\section{9}

Jan Introduction of Euro currency

Mar Allocation of new car registration letters switched from yearly in August to twice yearly

Energy tax announced at Budget

Apr Introduction of Individual Savings Accounts (ISAs)

replaces Personal Equity Plans and TESSAs

Introduction of national minimum wage

Advanced Corporation tax abolished

Jun The Bank of England 'repo' rate reduced to low point of 5.0 per cent

\section{0}

Feb House price growth peaks at 15 per cent in January and February

Oil price rises to highest level in 10 years

The UK company Vodafone takes over the German company Mannesman for $\mathrm{f} 113$ billion
Apr Government announces issue of $3 \mathrm{G}$ mobile phone spectrum licenses

May Share prices for internet companies start falling Competition commission finds that UK car prices are high relative to EU prices

BMW sells Rover and Ford shuts Dagenham plant

June Inward investment in the UK hits record levels, with a large proportion made up of take-over deals

July Hauliers and farmers stage large scale protests over the price of fuel

Aug European banking regulators investigate $£ 117$ billion of new loans made to telecommunications companies, reflecting concerns that banks have overlent to the sector

Nov George W Bush elected US President

Dec US GDP growth slows sharply, following prolonged expansion

\section{1}

Jan The US Federal Reserve cuts interest rates twice in one month, by 0.5 per cent each time

Feb The FTSE share price index falls below 6,000 points

Apr It emerges that Japan's bad debt problems are even worse than feared

May In the UK, business insolvencies are at a six-year high

Jun Pharmaceutical company Glaxo sheds 18,000 staff, 7 per cent of its UK workforce

Sep Terrorist attacks in United States. The World Trade Centre in New York is destroyed

Oct The US and its allies attack Afghanistan Argentina devalues its currency and defaults on its debt of $\$ 155$ billion, the biggest default in history

Railtrack collapses after the Government refuses to give further subsidies

Nov Bank of England cuts interest rates from 4.5 per cent to 4.0 per cent

Dec In the third quarter of 2001, US GDP shrinks for the first time in eight years

Enron, the 8th largest company in the United States, collapses leading to concerns about accountancy practices, banking involvement and financial market regulation

\section{2}

Jan Euro notes and coins enter circulation

Apr UK tax rises announced to fund NHS 
Jun WorldCom collapses - the biggest corporate failure in history

Network Rail takes over the running of the railways

Aug IMF announces a $\$ 30$ billion loan for Brazil, its biggest ever bailout of a struggling economy

Oct UK housing boom peaks as house price inflation reaches 30 per cent

Nov US Federal Reserve cuts interest rates to 1.25 per cent - a 40 year low

Slowing UK economy forces doubling of the estimate of public borrowing

Dec ECB cuts interest rates for the first time in more than a year, from 2.75 per cent to 2.5 per cent

Stock markets around the world fall sharply over the second half of the year, with the FTSE 100 dropping below 4,000

\section{3}

Jan The FTSE 100 drops by nearly 50 per cent since its peak in 1999, reaching its lowest level since 1995

UK economic growth at its lowest level since 1992, at 1.8 per cent per annum

UK manufacturing jobs fall to their lowest level since records began

Feb UK interest rates reduced by 0.25 per cent to 3.75 per cent due to weak internal and external demand

Mar Second Gulf war begins

Jul UK interest rates reduced by 0.25 per cent to 3.5 per cent, the lowest since January 1955, due to weak demand

Nov UK interest rates raised by 0.25 per cent to 3.75 per cent

Dec UK inflation target changes to 2.0 per cent based on the Consumer Prices Index (CPI)

\section{4}

Feb UK interest rates raised by 0.25 per cent to 4.0 per cent

May UK interest rates rise 0.25 per cent to 4.25 per cent Price of oil breaches $\$ 40$ barrier

Petrol prices reach 80p a litre

June The US Federal Reserve raises interest rates by 0.25 per cent to 1.25 per cent UK interest rates rise 0.25 per cent to 4.5 per cent

July Gordon Brown releases 2004-05 Spending Review

Aug Bank of England raises interest rates 0.25 per cent to 4.75 per cent
Nov George W Bush wins US election

\section{5}

Mar The US Federal Reserve raise interest rates by 0.25 per cent to 2.75 per cent

May Labour win general election, Tony Blair remains Prime Minister

June Oil reaches near $\$ 60$ a barrel - due to proposed strike in Norway

July London wins right to host Olympics in 2012

Terrorist attacks in London

Aug Bank of England cuts interest rates by 0.25 per cent to 4.5 per cent

Hurricane Katrina hits the US

US crude oil prices breach $\$ 70$ a barrel

Oct UK house price inflation hits nine-year low of 2.2 per cent in October according to Office of the Deputy Prime Minister

Dec European Central Bank (ECB) raises interest rates by 0.25 per cent to 2.5 per cent

The US Federal Reserve raises interest rates for the 13th consecutive time by 0.25 per cent to 4.25 per cent

\section{6}

Jan Ukraine/Russia gas dispute leads to cuts in gas supplies to Europe

The US Federal Reserve raises interest rates by 0.25 per cent to 4.5 per cent

Mar ECB raises interest rates by 0.25 per cent to 2.5 per cent FTSE breaks 6,000 barrier

The US Federal Reserve raises interest rates by 0.25 per cent to 4.75 per cent

May The US Federal Reserve raises interest rates by 0.25 per cent to 5.0 per cent

Oil prices rise above $\$ 73$ a barrel

State pension age to rise to 68 from 2044

June Oil reaches $\$ 74$ a barrel in response to Iran nuclear dispute ECB raises interest rates by 0.25 per cent to 2.75 per cent The US Federal Reserve raises interest rates by 0.25 per cent to 5.25 per cent

July Israel-Lebanon conflict pushes oil to $\$ 78$ a barrel Japan's Central Bank raises interest rate from 0.00 per cent to 0.25 per cent - the first increase in six years 
Aug Bank of England raises interest rates by 0.25 per cent to 4.75 per cent

ECB raises interest rates by 0.25 per cent to 3.0 per cent

Sep At $\$ 64.55$, oil prices fall to their lowest level since the end of March

Greece announces 25 per cent increase in annual GDP after a new GDP calculation is applied

Oct ECB lifts repo rate by 25 basis points to 3.25 per cent World output increases by 5.2 per cent in the year to the second quarter

Nov Bank of England raises interest rates by 0.25 per cent to 5.0 per cent

Dec The pound surges against the dollar - sterling is at its highest level since Black Wednesday

The ECB increases interest rates by 0.25 per cent to 3.5 per cent

OPEC agrees to cut oil production from the 1st February 2007

\section{7}

Jan Bank of England raises interest rates by 0.25 per cent to 5.25 per cent

The euro has displaced the US dollar as the world's leading currency in international bond markets

Feb FTSE 100 hit a six-year high after a flurry of takeover speculation

Mar ECB lifts repo rate by 0.25 per cent to 3.75 per cent

Apr Sterling moves past the $\$ 2$ mark for the first time since 1992

May Bank of England raises interest rates by 0.25 per cent to 5.5 per cent

June Tony Blair resigns - Gordon Brown becomes Prime Minister

Aug The financial crisis begins with central banks intervening on a large scale as banks around the world stop lending to each other

Sep Oil hits a new record high of $\$ 93.80$ a barrel Sterling rises to a 26 year high of $\$ 2.0694$ against the dollar

Nov Crude oil futures hit a record closing high, finishing above $\$ 98$ a barrel

The three-month interbank interest rate hit 6.59 per cent UK house prices recorded their biggest fall in 12 years

Dec Bank of England cuts the rate of interest by 0.25 per cent to 5.5 per cent
The US Federal Reserve cut interest rates by 0.25 per cent to 4.25 per cent

2008

Jan Gold prices rise above $\$ 900$ a troy ounce for the first time ever as investors seek refuge from a weakening US dollar

Stock markets in London and Europe suffer their biggest one-day falls since September 11th 2001

Oil hits a new record high of $\$ 100$ a barrel

The US Federal Reserve cuts interest rates to 3.0 per cent

Feb Bank of England cuts the rate of interest by 0.25 per cent to 5.5 per cent

Chancellor Alistair Darling announces the nationalisation of Northern Rock

Oil hits a new record high of $\$ 101$ a barrel

Mar US dollar falls to a record low as the euro moves to above $\$ 1.56$

The pound drops to a record low of $£ 0.79$ against the euro

The US Federal Reserve cuts interest rates by 75 basis points to 2.25 per cent

Apr Oil prices surge to a record high above $\$ 122$ a barrel Bank of England cuts interest rates by 0.25 per cent to 5.0 per cent

May Crude oil hits a new record high of $\$ 124$ per barrel

Jun Crude oil prices surged to a record high of $\$ 140.39$ per barrel

Jul ECB increases eurozone rates to seven-year high (up to 4.25 per cent)

Aug Oil prices fall below $\$ 120$ for the first time in three months as fears on world growth intensify

Sep Oil prices drop below $\$ 90$ a barrel

Nov Rates fall to a 54 year low. The Bank of England cuts base rates by 1.5 per cent to 3.0 per cent

ECB cuts rates by 0.5 per cent to 3.25 per cent

Dec Bank of England announces a rate cut to 2.0 per cent, the joint lowest for Bank Rate not matched since 1951 ECB cuts interest rates by 0.75 per cent to 2.5 per cent

\section{9}

Jan Rates fall to a 315-year low. Bank of England cuts interest rates to 1.5 per cent

ECB cuts interest rates by 0.5 per cent to 2.0 per cent 
Feb US Congress and Obama administration reach a deal on a $\$ 789$ billion economic stimulus package

European leaders outline proposals to regulate financial markets and hedge funds and clamp down on tax havens

Mar Share prices fall across the globe amid mounting fears over the financial health of banks and a spate of dividend cuts, Wall Street hits lowest levels since 1997

AIG reveals the depth of its financial plight with a $\$ 61.7$ billion quarterly loss

The EC unveil new regulatory and legislative measures designed to beef up supervision of Europe's financial institutions

Bank of England introduce quantitative easing, $\mathrm{f} 75$ billion to pump into the economy over the next three months

ECB cuts interest rates by 0.5 per cent to 1.5 per cent

The IMF will have its $\$ 250$ billion resources doubled to fight the financial crisis in emerging markets

Apr G20 leaders unveil a $\$ 1,100$ billion package of measures to tackle global downturn

Nine building societies, including Nationwide, have been down-graded by Moody's amid concern about their exposure to falling house prices and specialist mortgage loan

May Bank of England boosts its quantitative easing program by announcing the availability of a further $\mathrm{f} 50$ billion in Bank money

ECB cuts its main target rate by 0.25 per cent to

1.0 per cent and announces plans to purchase $\mathrm{f} 54$ billion in covered bonds

Oil surges to $\$ 63$ a barrel, with OPEC indicating that the global economy could withstand prices of between $\$ 75$ and $\$ 80$ a barrel

Jun General Motors to file for Chapter 11 bankruptcy protection

Ireland's credit rating is cut to double A, with a negative outlook, from double A plus

Lloyds banking group is to repay $\mathrm{f} 2.3$ billion to the Treasury, aimed at repaying the government's $\$ 4$ billion of preference shares

Bank of England announces that it will extend its Asset Purchase Facility to forms of working capital

ECB lends $€ 442$ billion to banks in bid to unlock credit markets

Jul Spanish bank Santander announces plans to strengthen it's balance sheets and improve its capital structure by offering to swap a nominal $€ 9.1$ billion ( $€ 7.8$ billion) in 30 securities for two new issues
Oil price drops below $\$ 60$ per barrel for the first time since mid-May as markets continued to react to latest US inventories data

The pay and bonuses of hundreds of high-flying City traders and dealmakers will have to be publicly disclosed under a Treasury-backed plan to curb excessive and risky remuneration

Nissan is to build a plant in the UK to make Lithium-ion batteries for electrical vehicles in one of the biggest new investments by a carmaker since the industry entered its downturn last year

Aug Oil increases to $\$ 73.50$ a barrel as commodities prices hit their highest level for the year

Bank of England boosts its quantitative easing program to $f 175$ billion

Sep World Trade Organisation gives Brazil the go ahead to impose $\$ 295$ million ( $\mathrm{f} 181$ million) of sanctions on US goods over Washington's failure to scrap illegal subsidies to its cotton farmers

BP, the UK energy group, has discovered a 'giant' oil field in the Gulf Of Mexico that shows a new frontier opening up for US oil production

Gold prices hit a six-month high, approaching the $\$ 1,000$ a troy ounce mark for the fifth time in two years

Dutch bankers are about to become the first in the world to cap bonuses paid to their most senior executives under a new code that will restrict such pay-outs to the equivalent of a year's salary

Oct Aviva are set to sell their stake in Dutch subsidiary Delta Lloyd, the biggest initial public offering in Europe for at least 18 months

Oil prices face further upward pressure as they near $\$ 80$ a barrel because of heavy trading in options contracts ahead of the year end

Nov Gold increases to an all-time high after India bought 200 tonnes of the precious metal

Government gives $£ 37$ billion of new bail out cash to RBS and Lloyds

Bank of England MPC slows the rate of its asset purchase injections into the UK economy

Dubai World a sovereign backed holding group, requests a delay on repayment of its liabilities (around $\$ 60$ billion)

Dec Greece faces possible ratings downgrade

Gold prices fall for a fourth session and commodity markets remain under pressure

Greece's bond markets see the largest collapse in the history of the Eurozone 
Standard \& Poor's change Spain's outlook from 'stable' to 'negative'

OPEC indicate that it aims to keep oil prices at $\$ 70-\$ 80$ per barrel next year as it tries to support the economic recovery

Bank of England's injection of cash into the economy has so far fallen short of the desired result, according to the Monetary Policy Committee

Iceland's parliament approves an amended bill to repay more than $\$ 5$ billion lost by savers in Britain and the Netherlands when the island's banks collapsed during the financial crisis

2010

Jan MPC votes to keep interest rates unchanged at 0.5 per cent

The recession has put a dent in future North Sea oil and gas production, with companies tapping fewer new oil reserves in 2009 than in previous years

Cadbury backs an improved $£ 11.6$ billion takeover bid from Kraft

Feb The European Union tell Greece to cut public sector wages and salaries and improve tax collection to prevent it's financial crisis from affecting the rest of the Eurozone Hector Sants resigns as chief executive of the Financial Services Authority

House prices fall for the first time in 10 months

Sterling falls to a nine-month low against the dollar and it's weakest level against the yen in 11 months

Mar Greece announces it is prepared to turn to the IMF if the euro area does not provide the support it wants

Germany and France plan to launch a 'European Monetary Fund'

EU talks on hedge funds and the private equity industry are on hold until after the UK general election

Leaders have agreed a eurozone rescue mechanism for Greece, giving the IMF a major role

Global steel prices are set to increase by up to a third after miners and steelmakers agreed a ground-breaking change in the iron-ore pricing system

Mergers and Acquisitions boomed in Asia in contrast to a slump in Europe and the US

Apr Parliament will be dissolved on the 13th April and an election called for the 6th May

Copper prices crossed the key $\$ 8,000$ a tonne barrier, leading other metals to their highest levels in 20 months
BA strike leads to a 15 per cent fall in passenger numbers in March, making it the worst March in a decade for passenger numbers

Eurozone members have committed to provide up to $€ 30$ billion in loans to Greece over the next year to stem the debt crisis

First live television debate between Labour, Conservative and Liberal Democrat leaders

Volcanic ash cloud strands passengers as air traffic across Europe's air space is halted

De Beers, the world's largest diamond miner, says the supply of the gems is running out over the long term

Standard \& Poor downgrade Spain's debt, sparking fears that Greece's debt crisis will spread to other Eurozone countries

The US stepped up it's response to the BP oil spill in the Gulf of Mexico

May Eurozone agrees a $€ 100$ billion package of emergency loans aimed at averting sovereign default by Greece and preventing a confidence crisis spreading to countries such as Spain and Portugal

UK General Election results in a hung parliament, both Conservatives and Labour hold talks with the Liberal Democrats over power sharing

Gordon Brown announces he will quit as Labour leader. David Cameron takes power, as the Conservatives and Liberal Democrats agreed a deal to form Britain's first coalition government since the Second World War

The price of Gold hits an all-time high

George Osborne (Chancellor) creates an independent fiscal watchdog, the Office for Budget Responsibility, to provide independent analysis of the UK's public finances including producing forecasts for the economy and public sector finances twice a year

Some of the world's largest hedge funds have experienced significant losses after high levels of volatility across markets wiped billions from portfolios

Sterling fell sharply due to the fear that Britain's public finances were worse than expected

Prudential launches $\$ 21$ billion rights issue to fund a takeover bid for the Asian businesses of AIG

Sanctions and under-investment have reduced Iran's oil production capacity by at least 300,000 barrels per day

George Osborne sets out plans for $£ 6.2$ billion of immediate public sector spending cuts

Share prices, commodities and the euro fell sharply 
President Obama orders a halt to the offshore drilling by oil companies following the BP spill

Jun China's central bank warns that property problems are more severe than those in the US

Pay freezes spread in the public sector

Retailers warn over VAT rise impact which could cost the UK economy $\mathrm{f} 24$ billion

Increase in the price of gold and demand for base metals drives growth of mining firms and share price in the FTSE 100

Bank of England holds interest rates steady

Oil drops after IEA forecasts oversupply

G20 backs drive for crackdown on banks

Jul UK group begins oil drilling in Arctic

China drives German recovery - exports rise 9.2 per cent

European banks in talks on bail-out fund

BP suffering from share losses since the Gulf oil crisis

Ministry of Defence looks at cutting 30,000 troops

President Obama signs bill to overhaul Wall Street

Emirates places $\$ 9$ billion order for Boeing 777s

Aug Wheat prices rise at fastest rate since 1973 as drought hits Russia

BP faces $\$ 20$ billion in penalties for oil leak

Inflation remains above the Bank of England's target

The coalition government set aside $£ 2$ billion to fight child poverty in the UK while the UK budget deficit as a proportion of GDP is 11 per cent

Sep Fears grow over food supply as Russia announced a 12-month extension of its grain export ban. The UN's Food and Agricultural Organisation held an emergency meeting to discuss the wheat shortage

ECB lifts eurozone growth forecast expecting the economy will grow 1.6 per cent in 2010 and 1.4 per cent in 2011, much higher than in the previous forecast

President Obama in $\$ 50$ billion plan to boost jobs

Trade deficit rises to postwar record

The CPI rate remains steady at 3.1 per cent partly because of higher commodity prices, in particular wheat which rose by 60 per cent since last year

US census showed that poverty in the age group 18 to 64 rose 1.3 per cent and is now at 12.9 per cent of the US population
Oct Ireland's deficit target reached 11.9 per cent of income and the government is expected to make further cuts

Greece plans to cut it's budget deficit to 7 per cent reaching a deficit of $€ 18.5$ billion this year and $€ 16.3$ billion for 2011

Iraq raises oil reserves by nearly 25 per cent

President of the European Central Bank considers an exit strategy for emergency support to financial institutions following strong eurozone output data and the euro's rise by 5 per cent since August

IMF report copper and tin price rises

Eurozone output as a share of total world output is falling British Banker's Association announce a $£ 1.5$ billion equity fund will be created to ease funding constraints to small and medium-sized enterprises in the UK

Cost of UK debt falls as Britain's borrowing costs have dropped to the lowest in a generation

US home values decrease in August, home prices fell 0.2 per cent from August to September

Nov Sugar prices soar to a 30 year high

Bank of England keeps interest rates at 0.5 per cent and the quantitative easing package at $\mathrm{f} 200$ billion

Decline in house prices continues, Halifax and Nationwide price indices declined by more than 1 per cent and Royal Institution of Chartered Surveyors housing price index dropped 0.2 per cent in October

Ireland's borrowing costs rise sharply

The price of copper reached $\$ 9,000$ a tonne

Food sales fell by 2.4 per cent in the three months to October

EU agrees $€ 85$ billion Irish bail-out

Dec Output grows at fastest rate in 16 years in the manufacturing sector

China pledges to purchase Greek bonds and increase foreign investment in countries such as Portugal to help tackle the crisis in the eurozone

Property prices fell by 4 per cent since June

Private investment in the third quarter was 24 per cent higher than a year ago

Copper rises to a record of $\$ 9,447$ a tonne, increasing by more than 50 per cent since June 